\title{
KÉPESSÉGFEJLESZTŐ JÁTÉKOK AZ IPOO-MODELL ASPEKTUSÁBÓL: A FEJLESZTÉSBE INTEGRÁLT DIAGNOSZTIKA LEHETŐSÉGE
}

\author{
Szerzők: \\ Dr. Mező Ferenc \\ Eszterházy Károly Egyetem \\ Dr. Mező Katalin \\ Debreceni Egyetem \\ Mező Lilla Dóra \\ Kocka Kör \\ Szerző e-mail címe: \\ ferenc.mezo1@gmail.com
}

Lektorok:

Mező F., Mező K. és Mező L. D. (2018): Képességfejlesztő játékok az IPOO-modell aspektusából: a fejlesztésbe integrált diagnosztika lehetősége. Különleges Bánásmód, IV. évf. 2018/2. szám, 55-66. DOI 10.18458/KB.2018.2.55

\begin{abstract}
Absztrakt
Mezö IPOO-modellje szerint a tanulás egyfajta információfeldolgozás, melynek négy különbözö, de egymással összekapcsolódó komponense van. Ezek az összetevök: input, process, output és organizáció. Ez a modell a tanulási jelenségek széles körének elemzésére, diagnosztizálására és fejlesztésére használható (a személyiségfejlesztéstöl a tanulási stratégiák és képességek fejlesztéséig). Jelen tanulmány rövid összefoglalót ad a képességdiagnosztika- és fejlesztés lehetöségeiröl az IPOO-modell elméleti keretében.

Kulcsszavak: képesség, fejlesztés, diagnosztika, IPOO-modell, játék

Diszciplina: pszichológia, pedagógia

Abstract

ABILITY DEVELOPMENT GAMES FROM ASPECTS OF IPOO-MODELL: THE POSSIBILITY OF DIAGNOSTICS INTEGRATED IN DEVELOPMENT

According to Mezö's IPOO-model of learning, the learning is a kind of information procesing, which has got four different, but related component. These component are: input, process, output and organization. This model is useable to analyzing and to diagnostic and to develop of wide range of learning phenomenons (from personaliy development to the development of learning strategies and abilities). Present study gives a short summarize about possibilities of ability diagnostics and development in theoretical frame of IPOOmodel.
\end{abstract}

Keywords: ability, development, diagnostics, IPOO-model, game

Disciplines: psychology, pedagogy 
Az IPOO-modell (Mező, 2002, 2004, 2011a) a tanulást négy komponensből álló információ-feldolgozó folyamatnak fogja fel. E komponensek dióhéjban a következők:

Input (információ bemenet). Az input kifejezés utalhat az információ felvétel során végzett (például észleléssel, információkereséssel, olvasással stb. járó) cselekvésekre, illetve a tanulás alapjául szolgáló (bármely érzékszervvel észlelt) információkra.

Process (információfeldolgozás): a felvett információk szelektálása, megértése, megőrzése, értékelése révén azok kognitív/emocionális feldolgozása.

Output (az információ felhasználása). Az output kifejezés utalhat a tanultak felhasználása során végzett cselekvésre (például beszédre, írásra, valamilyen nagymozgásos cselekvéssorra stb.), vagy e cselekvések eredményeként létrejövő (például szóbeli, írásbeli, rajzbeli, mozgásbeli stb.) produktumokra.

Organizáció (tanulásszervezés). Tanulásszervezési szempontból megkülönböztethetünk (akár nemzeti, iskolai, osztály, tanterv-tanmenet-óra-terv-gyakorlatterv szinten) szervezett, illetve spontán, a véletlenek összjátékaként bekövetkező tanulást. A szervezett tanulás során megtörténhet például a helyszín, a szükséges eszközök és személyek, az időbeosztás, a tevékenység vagy a finanszírozás (például tandíj biztosításának) tudatos koordinálása. Az önálló tanulás során a tanulásszervezés a tanuló feladata, máskülönben a tanulást koordinálók (például pedagógusok) folytatnak szervezőmunkát. Az organizáció szorzati viszonyban van a többi komponenssel - ok: a tanulásszervezés egyrészt hatással van a további komponensek mindegyikére, másrészt a tanulás elengedhetetlen tényezője (még ha spontaneitás is jellemzi).

E komponensek egymáshoz való viszonya képletszerüen:

$$
\text { Tanulás }=(\text { Input }+ \text { Process }+ \text { Output }) \times \text { Organizáció }
$$

Az IPOO-modell minden tanulási folyamat esetében használható keretrendszer. Genetikai és szerzett adottságaink mellett személyiségünket, mindenkori viselkedésünket, ismereteinket, értékeinket, normáinkat tanulás révén sajátítjuk el. A tanulás életünk minden pillanatában megnyilvánuló formái a tanuláselméletekhez köthetők: a klasszikus kondicionáláshoz, az operáns tanuláshoz, a szociális tanuláshoz, illetve a belátásos tanuláshoz. E tanuláselméletek sorrendjében inputnak tekinthetők például: az ingerek, az észlelt megerösítések, a modellről szerzett információk, vagy egy probléma és a korábbi megoldási kísérletek kudarcának észlelése. Outputnak tekinthetők az elsajátított válaszok, reakciók. Neobehaviorista megközelítéssel élve process-nek tekinthető az a kognitív/emocionális információfeldolgozás, ami az inputok alapján az outputot eredményeik. Az organizáció az input, process, output folyamatok szándékos szervezésére vagy spontán szerveződésére utal e tanuláselméletek megnyilvánulása alkalmával.

Az említett tanuláselméletek életünk jóformán minden pillanatát átható gyakoriságához képest jóformán ritka kivételnek tekinthető az iskolai jellegü, szándékos tanulás. Ugyanakkor az iskolai tanulás során is értelmezhető az input (információ bemenet, illetve a tananyag), a process (információ feldolgozás - például: megértés, memorizálás), az output (információ kimenet - például: felelés, dolgozatírás, tudás felhasználása, megtanult mozdulat bemutatása stb.). Az organizáció ebben az esetben jelentheti például a tanulás helyszínének, eszközeinek, időtartamának, folyamatának és finanszírozásának megszervezését.

Az IPOO-modell értelmezési keretet és módszertani lehetőségeket kínál például a személyiség- és viselkedés (újra)tanulását célzó terápiákhoz (Mező, 2016), a tanulási stílusok, stratégiák és taktikák (Mező, 2002), direkt tanulásfejlesztést szolgáló tanulásmódszertan (Mező, 2011.a,b), indirekt tanulásfejlesztést célzó képességfejlesztés (Mező, 2013, 2017) esetében. 
A tanulmány további részében ez utóbbi területre, a képességfejlesztésre fókuszálunk az IPOO-modellt tekintve elméleti keretnek. Mivel az IPOO-modellen alapuló képességfejlesztés fejlesztő játékokon keresztül valósul meg, mindenekelőtt a fejelsztő játék IPOO-modellben értelmezhető fogalmára kell kitérnünk.

\section{A fejlesztő játék}

Mező $(2017,35$. o.) meghatározása szerint: „A fejlesztő játék olyan gyakorlat(sor), amelyet kognitív vagy nonkognitív személyiségváltozók vagy valamilyen készség fejlesztése céljából alkalmazunk a gyakorlat végzésével kapcsolatos motiváció felkeltése és fenntartása érdekében játékos formában". E meghatározás indoklása a következő:

„A fejlesztő játék olyan gyakorlat(sor),...”: a fejlesztő játék képességet, készséget, szerepet stb. gyakoroltat - ennélfogva alkalmazható esetében a gyakorlat kifejezés is. A „fejlesztő játék" kifejezéssel utalhatunk olykor egy-egy különálló gyakorlatra is, de használhatjuk e fogalmat komplex, egymásra épülő gyakorlatsorozatra is.

„....amelyet kognitív vagy nonkognitív személyiségváltozók...”: kognitív személyiségváltozók például: érzékelés, észlelés, figyelem, emlékezet, képzelet, gondolkodás. Nonkognitív személyiségváltozók például: az egyénre jellemző szorongás, extraverzió, agresszió stb.

„...vagy valamilyen készség...”: a készségen teljesítményeket eredményező, konkrét tartalommal rendelkező, adottságok és képességek felhasználásával végzett begyakorolt müvelet, mely már nem igényel állandó gondolkodási kontrollt a végrehajtás során. Például: beszédkészség, olvasás, írás, számolás stb.

„...fejlesztése céljából alkalmazunk...”: a fejlesztő játék (legalábbis a fejlesztést végző személy szempontjából, ami nem biztos, hogy egyezik a gyermek, tanuló álláspontjával) nem öncélú, nem csak a játék kedvéért végzett tevékenység, hanem egy körülírt fejlesztési cél elérését célzó gyakorlat(sor).

„...a gyakorlat végzésével kapcsolatos motiváció felkeltése és fenntartása érdekében játékos formában.”: A gyakorlatok gamifikációja révén vonzóbbá, érdekesebbé tehetők a gyermekek számára azokat. A gyakorlatok természetesen nem játékos formában is végrehajthatók, amennyiben ez a fejlesztést igénybevevő kérése.

A fejlesztő játékokkal kapcsolatban az alábbi alapelveket fogalmazhatjuk meg:

A játékosság elve. A játékosság egyrészt megfelel a 3-10 gyermekek életkori sajátosságainak, s ezzel együtt segíthetnek a figyelmet és érdeklődést kiváltani, fenntartani, s a gyermekeket motiváltabbá tenni a feladatvégzés során.

Az interaktivitás elve. A csoportban történő játszás során törekedni kell a kortársak közötti kapcsolatteremtés révén a társas készségek alakítására. Egyéni fejlesztés esetén a fejlesztővel történő interaktív foglalkozásvezetés lehet a kulcsa szociális készségek fejlesztésének.

A partneri viszony kialakitásának elve. A fejlesztő játék során a gyermekkel bizalmi, partneri kapcsolat kialakítására kell törekednünk (a Rogers által megfogalmazott hitelesség, empátia és feltétel nélküli elfogadás ebben a kontextusban is lényeges!). A gyermeknek éreznie kell ugyan, hogy a pedagógus vezeti a foglalkozást, de amikor lehetséges, akkor a játék során felmerülő döntésekbe érdemes bevonni a játékost (többek között azért, mert a saját maga által létrehozott szabályokat hajlamosabb lesz elfogadni, mint a ráerőltetetteket).

A pozitiv énkép biztositásának elve. A fejlesztő pedagógusnak célszerü a „szendvicsmodellt" alkalmaznia a foglalkozások során, mely szerint egy bátorító kezdő feladat után fokozatosan nehezedő kihívások elé állítjuk a gyermekeket, majd végül az elsőhöz hasonló 
sikerélményt nyújtó feladvánnyal zárunk, hogy a pozitív énképet erősítsük a résztvevőkben. Fontos, hogy játék közben mind a tanuló és a társas környezete (család, pedagógusok, kortársak) számára kihangsúlyozzuk az egyén erősségeit.

A multifunkciós játékok preferálásának elve. Érdemes a több fejlesztési célra is alkalmas játékokat előnyben részesíteni a speciális csak egy adott mentális képesség nevelésére használhatókkal szemben. Kivételt jelenthet, amikor mindössze egy körülírt képesség fejlesztése a cél. Ugyanakkor megjegyzendő, hogy a kognitív képességek például nem függetlenek egymástól (például egy figyelem vizsgálatára alkalmazott gyakorlat során valójában az érzékelés, észlelés, emlékezet és esetleg a gondolkodás kontrollfolyamatai is megnyilvánulnak). Valójában, ha egyetlen adott célképességet célzunk meg a fejlesztő játékkal, akkor e feladat végrehajtását lehetővé tevő és egymásra kölcsönösen ható képességek közül mindössze egyetlen kiragadott képességre fókuszálunk, amelynek gyakoroltatása érdekében használjuk az adott játékot (annak tudatában azonban, hogy e képességet meglehetősen önkényesen ragadtuk ki a feladathoz ténylegesen szükséges képesség-együttesböl).

Háromszintü célrendszer alkalmazásának elve. A fejlesztő játékok tervezése, alkalmazása szempontjából célszerü egy háromszintü célrendszer alkalmazását követni. A legtágabb értelemben vett cél a „Misszió”, a fejlesztés általános célja, amit az adott játék révén (is) igyekszünk elérni (például: a figyelem fejlesztése). Egy szükebb értelemben vett direkt célt a gyermeknek szóló instrukció fogalmaz meg a feladat meghatározása során (például: „Karikázd be az alábbi szövegben az »a« betüket!”) - ezt a gyermek szempontjából tekinthetjük a gyakorlat közvetlen céljának. Végül, a gyermek szempontjából közvetett (elöle ugyan nem eltitkolt, de tőle talán kevesebb érdeklődést, megértést feltételezö), indirekt cél: a feladat szük értelemben vett szakmai célja (például: a figyelem mennyiségi és minőségi mutatójának a fejlesztése).

Személyorientáció és célorientáció közötti harmóniára törekvés elve. A fejlesztő tevékenység dilemmája lehet, hogy személy- vagy célorientált fejlesztés valósuljon-e meg. Ideális esetben a gyermek személyiségéhez szabott, ám egy adott célt szolgáló játékot kellene alkalmazni a fejlesztés során. A pedagógustól ez széleskörü módszertani repertoárt és/vagy játék-fejlesztői kompetenciát igényel - vö.: Mező (2017) többek között 120 fejlesztő játékot tartalmazó müvét, illetve Koncz (2006, 2008, 2012, 2015) müveit.

A folyamatjelleg elve. Néhány kivételesen ritka (katarktikus, traumatikus élményt feltételező) eset kivételével fejlesztő hatást a min. heti rendszerességü gyakorlástól, folyamatjelleggel alkalmazott játéktevékenységtől remélhetünk. Egy játék egyszeri müvelésétől nem várható drasztikus eredmény. Azonban 2-6 hónapot követő - akár napi, de legalább heti rendszerességü - gyakorlás után már van esély szemmel látható fejlődésre.

A változatosság elve. Ha foglalkozás élvezetes és a gyermek is motiváltabb lesz, ha változatos aktivitásokat ajánlunk számára a fejlesztés során. Ezt a fejlesztés céljára fókuszáló játékvariációk révén valósíthatjuk meg - például: a figyelem fejlesztése érdekében alkalmazott klasszikus papír-ceruzai feladatokat időnként auditív, vagy nagy-mozgásos válaszadást kívánó gyakorlatokkal variálhatjuk. Itt hívjuk fel a figyelmet arra, hogy a fejlesztő játékok az e- és m-learningben, a fejlesztést célzó gamifikált internetes felületekben rejlö lehetőségeket is felhasználhatják (vö.: Szabóné, 2007, 2009, 2010, 2011; Mező és Psenáková, 2009). Fromann és Damsa (2016) például az alábbi - játékos fejlesztésre is alkalmazható internetes felületeket mutatja be: 
1. ClassBadges: www.classbadges.com

2. ClassDojo: https://www.classdojo.com

3. Classtools: http://www.classtools.net

4. CourseHero: https://www.coursehero.com

5. Classcraft: http://www.classcraft.com

6. GoalBook: https://goalbookapp.com

7. Kidblog: http://kidblog.org/home/blog

8. Minecraft, MinecraftEdu: http://education.minecraft.net

9. Okosdoboz: http://www.okosdoboz.hu

10. OpenBadges: http://openbadges.org/

A strukturáltság elve. A fejlesztő játékokkal operáló foglalkozások általános (nem kötelezö, de gyakori és javasolt) felépítése Kovácsné és Pálfi (2015 alapján) a következő:

- Ráhangolás (például: hangulatteremtés, érdeklődés felkeltés, célok és szabályok tisztázása, kellékek és szerepek kiosztása, vagy akár egy több hetes játékfolyamat kerettörténetének indítása/folytatása - lásd: Mező és Mező, 2013).

- A játék folyamata (ebben a fejlesztő személy lehet a játék irányítója, résztvevője és „szurkolója” is egyben).

- Levezetés, a játék befejezése (tapasztalatok megbeszélése, visszajelzés nyújtása, ráhangolás a következő játékra).

A fejlesztö játék, foglalkozás(sorozat), program elve. Az egyedi, általában néhány perc időtartamú fejlesztő játékok 30-90 perces fejlesztő foglalkozásokba integrálhatók, e foglalkozások pedig foglalkozássorozattá, ideális esetben pedig minimum önkontrollos hatásvizsgálattal minőségbiztosított $10-120$ órás programokká szervezhetők. A fejlesztő programok esetében vagy egy elöre meghatározott foglalkozássorozat végrehajtása történik azonos (például tanulás módszertani) problémával rendelkező gyermekcsoporton belül, vagy egy foglalkozás-gyüjteményből választják ki differenciáltan a gyermekekre szabva a tevékenységeket. Az előző esetben a program szigorúan összeállított protokoll szerint valósul meg, amelyben a fejlesztőknek a programleíráshoz kell tartaniuk magukat. Az utóbbi esetben a program keretjellegü, és a fejlesztőknek nagy módszertani szabadságot enged.

Ismertebb külföldi programok például: Philosophy for Children program (rövidítve: P4C vagy PfC), ami a kritikai gondolkodás fejlesztésére fókuszál (Lipman és Bynam, 1976); Instrumental Enrichment (IE) program (Feuerstein és tsai, 1980; vö.: János, Batiz és Farcas, 2015; Kiss, Orbán és Maior, 2015); CASE (Cognitive Acceleration through Science Education) program (Adey, Shayer és Yates, 1989); Intelligence Applied program Sternberg (1986); Metacognitive Thinking Training (Resing, 1996); Sindelar-program (Sedlak és Sindelar, 2005, Zsoldos, 2002) kognitív képességeket fejlesztő programja.

A szenzomotoros fejlesztő foglalkozások és a fejlesztő pedagógia hazai úttörője Porkolábné Balogh Katalin (1989, 2002, 2009), akinek (óvodai testnevelésbe illeszthetö) programja az észlelésre, a mozgásra, a testsémára és a verbalitásra fókuszál. Tanulási zavarral küzdő kisiskolásoknak szóló készségfejlesztő eljárásokkal kapcsolatos ajánlásaival kapcsolatban lásd: Porkolábné (2005).

Gyarmathy Éva (1998) foglalkozásgyüjteményében a testsémát, egyensúlyt, térbeli orientációt célzó mozgásfejlesztés mellett a látás, hallás és tapintás útján történő észlelés, valamint a térbeli, időbeli, illetve verbális sorba rendezés terén is segítséget nyújt az öt és tíz év körüli, alapfunkciókban lemaradást gyermekeknek.

A 3-10 éves korosztályt célozza Kelemen Lajos, Törökné Drubics Éva és Varjúné Legát Katalin „Okoskocka” eszközcsaládja, melynek tagjai a vizuális és akusztikus észlelés, számolás, test-séma, térészlelés, anyanyelv, illetve mese- és szövegértés fejlesztésére 
koncentrálnak (Kelemen, 2014, 2015). Az Okoskocka fejlesztő eszközcsalád célja (www.okoskocka.hu):

- a 3-10 éves korú gyermekek mentális képességeinek kibontakoztatása.

- Az iskolai tanulást, illetve a számolást, írást és olvasást megalapozó képességek fejlesztése.

- A szülők tájékoztatása a gyermek kognitív képességeiröl, fejlődéséről.

- Segítségnyújtás a tanulási nehézségek megelőzése, kezelése tekintetében.

- Tehetségazonosítás és -gondozás elősegítése.

Itt hívjuk fel a figyelmet Szebeni, Dorner és Hanák (2015) a tanári és tanulói személyiségés képességfejlesztés elméleti és módszertani lehetőségeit összefoglaló müvére, valamint Hanák (2009) hátrányos helyzetü tanulók továbbtanulását támogató speciális tréningprogramokra fókuszáló, s Hanák (2016) óvodai kommunikációs készségfejlesztésre fókuszáló írására.

A hazai fejlesztőprogramok egyik széles spektrumú családját alkotják a Mező (2002, 2011a,b, 2017) által kidolgozott IPOO-modellre (korábbi nevén: IPOO-modellre) épülö fejlesztő programok, keretrendszerek. Ezek:

- IPOO személyiség-, viselkedés- és magatartásformáló eszköztár (lásd: Mezö, 2016), mely a fejlesztést végzők által kontrollált információ bemenet, -feldolgozás, felhasználás, és ezek megszervezése révén teszi lehetővé a személyiség-, viselkedésés magatartásformálást, miközben a klasszikus kondicionálás, az operáns, a szociális és a belátásos tanulás módszertani lehetőségeit alkalmazza. Alkalmazása kézikönyv (Mezö, 2016) és 30 órás akkreditált pedagógus továbbképzés révén sajátíthat el (további információ: www.kpluszf.com).

- IPOO-minimum program (korábbi nevén: IPOO-minimum program; Mező, 2002, 2011b,c): a kreatív (produktív, információt termelö) tanulás fejlesztésére szolgáló módszertani program.

\begin{abstract}
Az IPOO-modell három tanulási stratégiát különböztet meg az input (például: tananyag) és az output (például: számonkérés) mennyiségi és minőségi viszonya alapján; ezek: a) improduktív (információveszteséggel járó) tanulás (Input > Output), b) reproduktív (megértés nélküli, magolós) tanulás (Input = Output), c) produktív (megértésre törekvő, alkotó jellegü, információt termelö) tanulás (Input < Output).
\end{abstract}

A program elsajátításához 30 órás akkreditált továbbképzés, tanári kézikönyv (Mezö, 2011b) és tanulói munkafüzet (Mező, Mező és Mező, 2009) áll rendelkezésre (lásd: www.kpluszf.com). Az eljárás alapján nemzetközi tanulás módszertani verseny és interaktív tananyag is rendelkezésre áll (info: www.kpluszf.com).

- IPOO-tanulási képességfejlesztő játékcsomag. Érzékelést, észlelést, figyelmet, emlékezetet, fogalomalkotó és algoritmikus gondolkodást, valamint kreativitást fejlesztő program. Gyakorlati példatárt (120 fejlesztő játékot) is tartalmazó kézikönyv (Mezö, 2017) és pedagógus továbbképzés során sajátítható el.

Az IPOO-modell teoretikus hátteret, elméleti keretet ad a fejlesztés, és a fejlesztést szolgáló diagnosztika számára. Tekintsük át ennek lényegesebb pontjait!

\title{
Fejlesztésbe integrált diagnosztika az IPOO-modellen alapuló képességfejlesztés során
}

Noha az IPOO-modell szerint alkalmazott játékok elsősorban a fejlesztést szolgálják, de ,a diagnosztikára alkalmas játéktípus a fejlesztésre is alkalmas, s a fejlesztésre használt játék 
diagnosztikára is használható" elv alapján a játékosok megismerésének eszközéül is szolgálhatnak.

A diagnosztika legegyszerübb esete, amikor egy játékalkalommal megfigyeljük egy játékos teljesítménybeli, viselkedésbeli adatait (például a megoldáshoz szükséges időt, a feladat során elért mennyiségi mutatókat, vagy a megoldás minőségét), majd a további játékok során figyeljük, hogy ezen eredmények romlanak, stagnálnak vagy javulnak-e. Egy játék során nyújtott teljesítményeket egy adott kritériumszinthez is hasonlíthatjuk, mely kritériumszint (például: egy adott pontszám, érték elérése egy skálán) elérése lehet kritériumorientált fejlesztésünk célja. Egy másik lehetőség a fejlesztés előtti és utáni diagnosztikai eredmények összevetése - elégedettek lehetünk a fejlesztéssel, ha az eredmények javuló tendenciáról árulkodnak. Lehetőség van továbbá kontrollcsoportos vizsgálatokra is: a tanulók egy csoportját bevonjuk a fejlesztő játékokba, egy másik (kezdetben az előzőhöz lehetőleg minél jobban hasonlító) csoportot pedig nem, s megnézzük, hogy a fejlesztő játékok eredményeként nött-e köztük a különbség. Végül: nyomonkövetéses vizsgálatokhoz is információt szolgáltathat az IPOO-modell alapján végzett diagnosztika.

Az IPOO-modell elméleti keretében a fejlesztőjáték teljesítmény az input, a process, az output és az organizáció komponensek összjátékának az eredménye - így a fejlesztőjátékbeli teljesítmény e komponensekről is nyújthat diagnosztikai értékü információt. A fejlesztőjátékok sikeres megoldásának előfeltétele az instrukció input komponensének megértése (pl. a gyermek megérti, hogy meg kell hallgatnia valamit) és megvalósítása (pl. a gyermek képes a hallásra). Ennek diagnosztikai következményei (vö.: 1. ábra):

a) amennyiben a játék egészében sikeresen vesz részt a gyermek, akkor az arra utal, hogy megérttette és teljesíteni tudta az instrukció input komponensének felhívását (is);

b) egy összességében sikertelen játék esetében is elöfordulhat olyan helyzet, hogy az inputra vonatkozó instrukciórészletet sikeresen meg tudta oldani a gyermek, s erröl talán a játéktevékenység megfigyelése során meg is győződhetünk. Ilyen esetben a többi komponens elemzésére kell fordítani a figyelmünket, ha a sikertelenség okát (másképp: a fejlesztendö területet) keressük.

c) egy összességében sikertelen játék alkalmával elemezhetjük, hogy mi volt a sikertelenség oka, s előfordulhat, hogy arra jutunk, hogy az instrukció input komponensének megértésével volt gond, és/vagy az adott input modalitás(ok) esetében az érzékszervek és/vagy a szenzoros idegpályák morfológiai vagy fiziológiai fejletlensége/károsodása gyanítható.

A fejlesztőjátékbeli teljesítményt determináló másik feltétel az instrukció process komponensének megértése (pl. a gyermek megérti, hogy meg kell jegyeznie valamit) és megvalósítása (pl. a gyermek képes a megjegyzésre). Diagnosztikai következmények (vö.: 2. ábra):

a) amennyiben a játék egészében sikeresen vesz részt a gyermek, akkor az arra utal, hogy megérttette és teljesíteni tudta az instrukció process komponensének felhívását is.

b) egy összességében sikertelen játék esetében is elöfordulhat olyan helyzet, hogy a processre vonatkozó instrukciórészletet sikeresen meg tudja oldani a gyermek, ám problémái adódnak az input során (pl. rosszul hallja a megjegyzendő szót, ezért rossz információt memorizál) és vagy az output alkalmával (pl. bár megjegyezte, amit kellett, de válaszában nem tud kiejteni helyesen az egy vagy több hangot, nem tud helyesen leírni egy vagy több adott betüt).

c) egy összességében sikertelen játék oka lehet az instrukció process komponensének megértésbeli gondja is (például a gyermek nem ismeri a „memorizáld” szót), és/vagy intellektuális (rész)képesség probléma is. Ez utóbbi hátterében a központi idegrendszer morfológiai vagy fiziológiai fejletlensége/károsodása gyanítható. 
1. ábra: a fejlesztöjátékok és instrukciójuk input komponensének diagnosztikai elemzö sémája (forrás: a Szerzök)

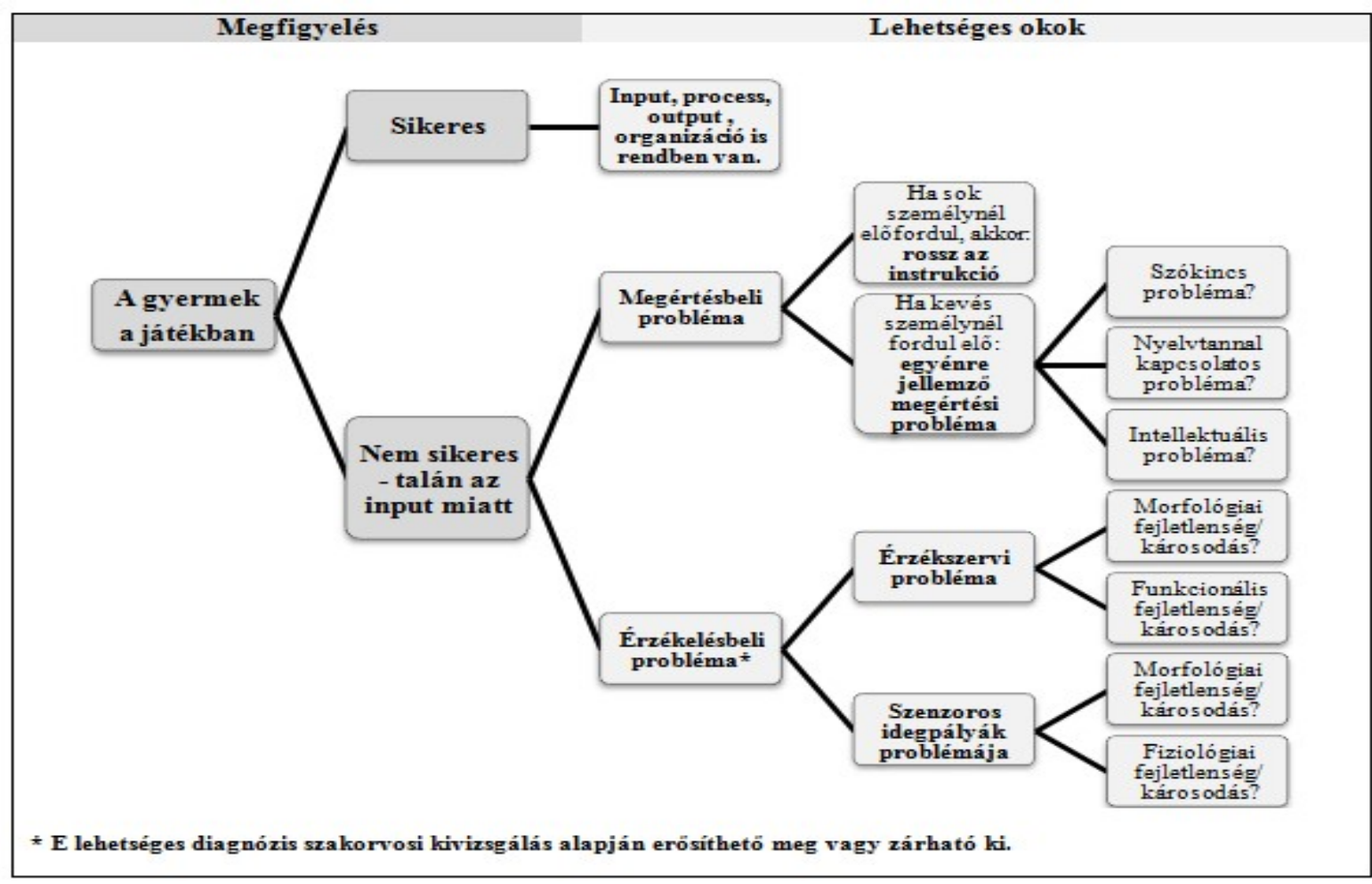

2. ábra: a fejlesztőjátékok és instrukciójuk process komponensének diagnosztikai elemzö sémája (forrás: a Szerzök)

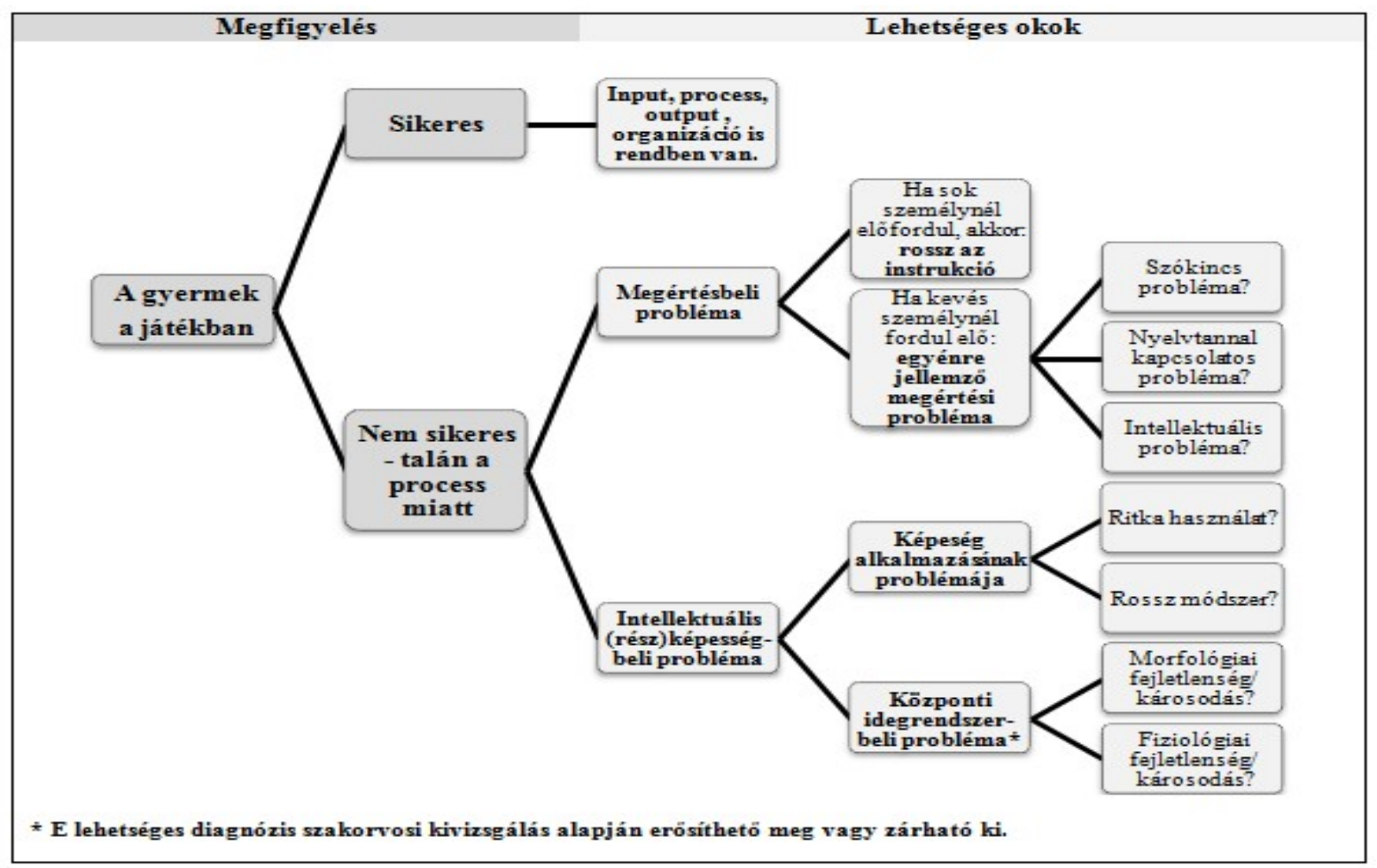


Az instrukció output komponensének megértése (pl. a gyermek megérti, hogy írásban kell válaszolnia) és megvalósítása (pl. a gyermek tud írni) is hatással van fejlesztőjátékbeli teljesítményre - ennek diagnosztikai következményei (vö.: 3. ábra):

a) a játékban történő sikeres részvétel arra utal, hogy a játékos megérttette és teljesíteni tudta az instrukció output komponensében közölteket is.

b) egy összességében sikertelen játék esetében is előfordulhat olyan helyzet, hogy az outputra vonatkozó instrukciórészletet sikeresen tudna végrehajtani a játékos (helyesen, szépen tud írni például, ha írásban kell válaszolnia), azonban problémái adódnak az input során (például rosszul hallja a megjegyzendő és később leírandó szót) és/vagy a process alkalmával (például a rövid távú memóriája átlag alatti színvonalon müködik).

c) egy összességében sikertelen játék hátterében állhat az instrukció output összetevőjének megértésével kapcsolatos probléma is (például a játékos nem ismeri a „Készíts listát!” kifejezést), és/vagy motorikumot érintő probléma is (a fejletlen csont-, izom-, ízületi rendszertől a motoros idegpályák morfológiai/fiziológiai fejletlenségéig vagy károsodásáig terjedően).

3. ábra: a fejlesztöjátékok és instrukciójuk output komponensének diagnosztikai elemzö sémája (forrás: a Szerzők)

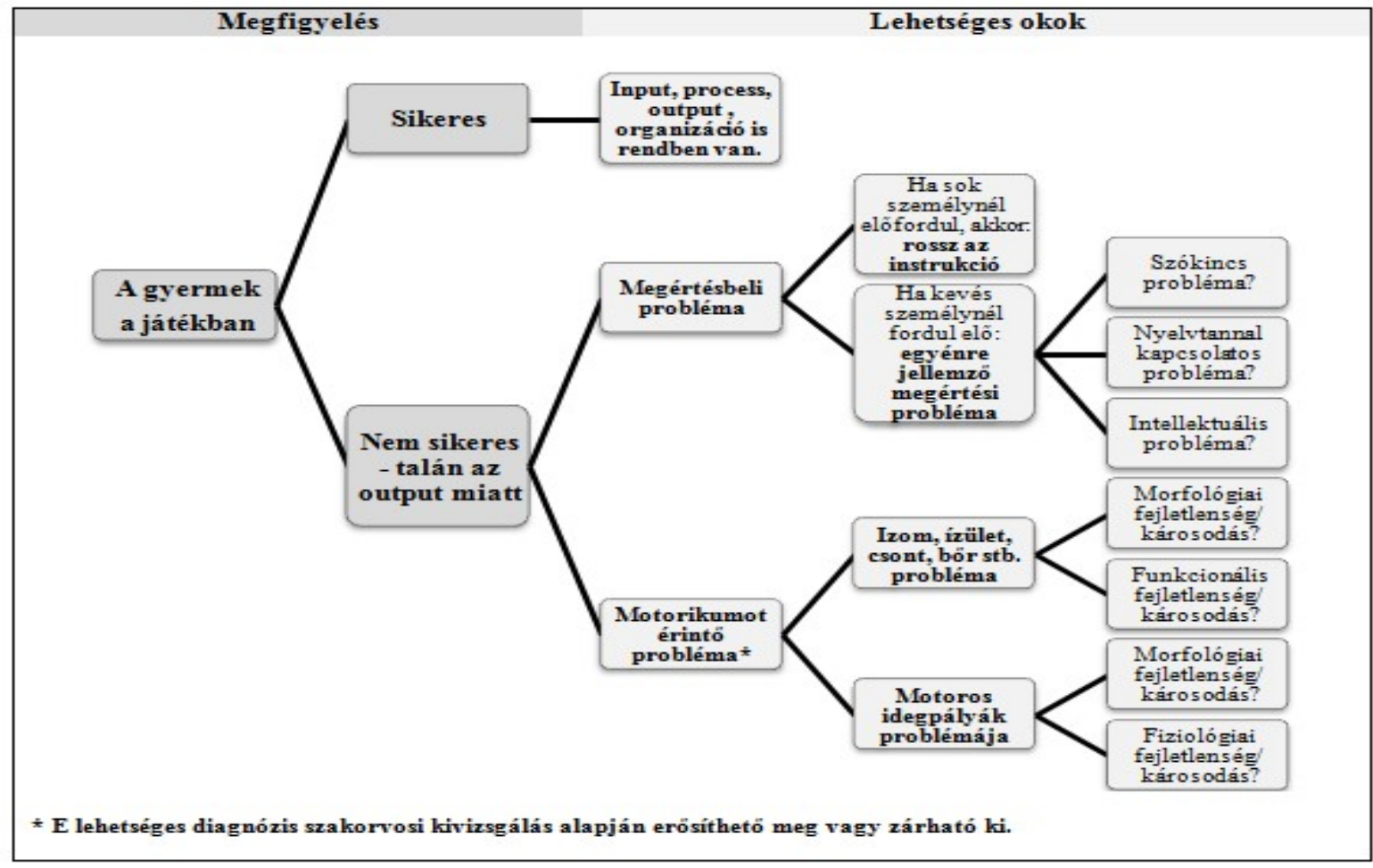

A szervezés (organizáció) ugyan nem jelenik meg az instrukcióban, azonban a fejlesztési folyamat szervezettsége is hatással van a fejlesztésre, illetve a fejlesztő játékbeli eredményességre, ennélfogva az organizációra vonatkozó diagnosztika is megvalósítható (bár ez nem a fejlesztett gyermekről, hanem a szervezést végrehajtó fejlesztőről és környezetbeli lehetőségekről nyújthat információt). 


\section{Összefoglalás}

Az IPOO-modell szerint a tanulás (beleértve a képességek gyakoroltatását, fejlesztését is) olyan információfeldolgozási folyamat, amelyet a szervezettsége (organizáció), az információ bemenet (input), feldolgozás (process) és felhasználás (output) jellemez. Az IPOO alapú képeséségfejlesztés során a fejlesztő feladata a körülmények (például: helyszín, eszközök, időbeosztás stb.) biztosítása, $\mathrm{s}$ a játékvezetésen belül egy legalább három (inputra, processre és ouputra vonatkozó) tagmondatból álló instrukció adása a lehetőségek szerint gamifikált feladatok meghatározásakor.

A IPOO-modell alapján a képességfejlesztés folyamata nemcsak elemezhető, tervezhető, hanem a fejlesztéshez szükséges diagnosztika is megvalósítható.

\section{IRODALOM}

Adey, P.S., Shayer, M. és Yates, C. (1989). Thinking Science: Student and Teachers' materials for the CASE intervention. London: Macmillan

Affolter, F. (1972): Az észlelési funkciók zavartalan és patológiás fejlődésének szempontjai. In: Torda Ágnes (szerk.): Szemelvények a tanulási zavarok köréböl. Nemzeti Tankönyvkiadó, Budapest. 87-95

Feuerstein, R., Rand, Y., Hoffman, M. B. és Miller, R. (1980). Instrumental enrichment: An intervention program for cognitive modifiability. Balitmore, MD: University Park Press.

Fromann Richárd és Damsa Andrei (2016): A gamifikáció (játékosítás) motivációs eszköztára az oktatásban. Új Pedagógiai Szemle, 2016/3-4. 76-81. o.

Gyarmathy Éva (1998): A tanulási zavarok terápiája. Új Pedagógiai Szemle 48. évf/12. szám, 1998, 75-87.

Hanák Zsuzsanna (2009): Problémák és megoldások: Hátrányos helyzetü tanulók továbbtanulásának támogatása speciális tréningprogramok segítségével. In: Bábosik István és Torgyik Judit (szerk.): Az iskola szocializációs funkciói. Eötvös József Könyvkiadó, Budapest. 178-186.

Hanák Zsuzsanna (2016): Kommunikációs készségfejlesztés az óvodában. In: H. Tomesz Tímea és H. Varga Gyula (szerk.): Kommunikációs készségfejlesztés a pedagógiai munkában. Hungarovox Kiadó, Budapest. 81-89.

János Réka, Batiz Enikő, Farcas Susana (2015): Dinamikus eljárások a tanulásban akadályozott gyermekek kognitív potenciáljának értékelésében. In: Szilágyi Barnabás, Mező Katalin és Mező Ferenc (szerk.): Az együttnevelés útjai. Debreceni Egyetemi Kiadó, Debrecen. 151-166.

Kelemen Lajos (2014): A kognitív képességek rendszere és fejlődési szintjei a kultúrtechnikák elsajátítása aspektusában. In: Tánczos Judit (szerk.): Fejlesztő pedagógiai és pszichológiai tanulmányok I. Debreceni Egyetemi Kiadó, Debrecen. 45-60.

Kelemen Lajos (2015): A tanulási korlátokkal küzdő gyermekek beszéddiagnosztikája és fejlesztése az okoskocka eszközökkel. In: Mező Katalin (Szerk.): Játékkal a különleges bánásmódot igénylö gyermekekért. Bíbor Kiadó, Miskolc. 39-53.

Kiss Szidónia, Orbán Réka és Maior Edit (2015): A mediált tanulási tapasztalat alkalmazása a tanulásban akadályozott gyermekek fejlesztésére. In: Szilágyi Barnabás, Mező Katalin és Mező Ferenc (szerk.): Az együttnevelés útjai. Debreceni Egyetemi Kiadó, Debrecen. 167187.

Koncz István (2006): A pedagógusszerep. In: Balogh László: Pedagógiai pszichológia az iskolai gyakorlatban. Urbis Könyvkiadó, Budapest. 247-305. 
Koncz István (2008): A kiterjesztett tehetséggondozás és személyiségfejlesztés. In: Balogh László és Koncz István (Szerk.): Kiterjesztett tehetséggondozás. Professzorok az Európai Magyarországért., Budapest. 117-143.

Koncz István (2012): Videós önismeretfejlesztés. Fapadoskönyv Kiadó, Budapest.

Koncz István (2015): Sikeres trénerek nagy kézikönyve. FITT IMAGE Kft., Budapest.

Kovácsné Bakosi Éva és Pálfi Sándor (2015): A fejlesztő játékok módszertani alapjai. In: Szilágyi Barnabás, Mező Katalin és Mező Ferenc (szerk.): Az együttnevelés útjai. Debreceni Egyetemi Kiadó, Debrecen. 217-240.

Lipman, M. és Bynam, T. W. (Eds.)(1976). Philosophy for Children. Oxford: Basil Blackwell.

Mező Ferenc (2002, 2004): A tanulás stratégiája. Pedellus Novitas Kft., Debrecen.

Mező Ferenc (2011a): Tanulás: diagnosztika és fejlesztés az IPOO-modell alapján. $\mathrm{K}+\mathrm{F}$ Stúdió Kft., Debrecen

Mező Ferenc (2011b): Az IPOO-minimum kreatív tanulásfejlesztő program hatásvizsgálata. In: Münnich Ákos (szerk.): A kreativitás többszempontú vizsgálata. Didakt Kiadó, Debrecen. 111-134.

Mező Ferenc (2016): A viselkedés elemzése és fejlesztése. K+F Stúdió Kft., Debrecen.

Mező Ferenc (2017): Fejlesztő pedagógia - Elmélet és gyakorlati példatár a képességfejlesztés köréböl. Kocka Kör, Debrecen.

Mező Ferenc és Mező Katalin (szerk.)(2013): Képességfejlesztés - elmélet és példatár. Debreceni Egyetemi Kiadó, Debrecen.

Mező Ferenc (2017): Fejlesztő pedagógia - Elmélet és gyakorlati példatár a képességfejlesztés köréböl. Kocka Kör, Debrecen.

Mező Ferenc, Mező Katalin és Mező Lilla Dóra (2009): Tanulógép: Tanulás módszertani javaslatok. Kocka Kör Tehetséggondozó Kulturális Egyesület, Debrecen.

Mező Ferenc és Psenáková Ildikó (2009): A képességfejlesztés lehetőségei az e-learning és m-learning révén. In: Ildikó Psenáková, Ferenc Mező és Ildikó Viczayová (szerk.): Teória a prax II. Nitra: Univerzita Konstantina Filozofa v Nitre. 119-129.

Porkolábné Balogh Katalin (1989): Óvodai fejlesztés a tanulási zavarok megelözésére. Pedagógiai füzetek. Heves Megyei Tanács Pedagógiai Intézete, Eger.

Porkolábné Balogh Katalin (2002): A korai prevenciós fejlesztés. In: Mártonné Tamás Márta (szerk.): Fejlesztö pedagógia - A fejlesztés föbb elméleti és gyakorlati eljárásai. ELTE Eötvös Kiadó, Budapest. 11-31.

Porkolábné Balogh Katalin (2005): Készségfejlesztő eljárások tanulási zavarral küzdő kisiskolásoknak. Iskolapszichológia 4. ELTE PPK, Budapest.

Porkolábné Balogh Katalin, Balázsné Szücs Judit és Szaitzné Gregorits Anna (2009)(szerk.): Komplex prevenciós óvodai program - Kudarc nélkül az iskolában. Trefort Kiadó, Budapest.

Resing, V.C.M. (1996). Untersuchung zur Lernfahigkeit bei Kindern: Die Auswirkungen eines metakognitiven Denktrainings. Zeitschrift für Entwicklungspsychologie und Pedagogische Psychologie, 28 (1996), 1, 33-53.

Sedlak, Franz és Sindelar, Brigitte (2005): De jó, már én is tudom! Óvodáskorú és iskolát kezdö gyermekek fejlesztése. A/3 Nyomdaipari és Kiadói Szolgáltató Kft., Budapest.

Sternberg, R. J. (1986). Intelligence applied: Understanding and increasing your intellectual skills. San Diego: Harcourt Brace Jovanovich

Szabóné Balogh Ágota (2007): Számítógépes lehetőségek a fejlesztő pedagógiában,különös tekintettel a szövegértés fejlesztésére. In: Virágné Horváth Erzsébet (szerk.): Diskurzus. TSF PFK, Szarvas, 151-162. o. 
Szabóné Balogh Ágota (2009): Digitális eszközök alkalmazása a szövegértés fejlesztésében, In: Karlovitz János Tibor (szerk.): Gyakorló Pedagógusok és a pedagógia gyakorlata. Neveléstudományi Egyesület, Budapest. 57-66. o.

Szabóné Balogh Ágota (2010): Képességfejlesztő digitális tananyagok, szoftverek ismertetése (egy mikrokutatás tapasztalatai). In: Pšenáková, Ildikó és Mező Ferenc (Szerk.): Képességfejlesztés digitális tananyaggal. Kocka Kör, Debrecen. 69-87.

Szabóné Balogh Ágota (2011): Algoritmikus gondolkodás fejlesztése informatikai eszközökkel. In: Koncz István (szerk.): A felsőoktatásban tanulók és tanáraik személyiségét érö új kihívások és kezelésük (elektronikus könyv). Professzorok az Európai Magyarországért Egyesület, Szarvas-Budapest. 71-75. o. Letöltés: 2017.05.01. Web: http://www.peme.hu/userfiles/ELEKTRONIKUS\%20K\%C3\%96NYV(3).pdf

Szebeni Rita, Dorner László és Hanák Zsuzsanna (2015): Tanári - tanulói személyiség - és képességfejlesztés elméleti és módszertani lehetöségei. EKF Líceum Kiadó, Eger.

Zsoldos Mária (2002): Kognitív fejlesztő terápia a tanulási zavarok keze-lésében. Brigitte Sindelar kognitív fejlesztő programja. In: Martonné Tamás Márta (szerk.): Fejlesztő pedagógia - A fejlesztés föbb elméleti és gyakorlati eljárásai. ELTE Eötvös Kiadó, Budapest. 72-87. 